\title{
Abscisic Acid Induced Changes in Production of Primary and Secondary Metabolites, Photosynthetic Capacity, Antioxidant Capability, Antioxidant Enzymes and Lipoxygenase Inhibitory Activity of Orthosiphon stamineus Benth.
}

\author{
Mohd Hafiz Ibrahim ${ }^{1, *}$ and Hawa Z. E. Jaafar ${ }^{2}$ \\ 1 Department of Biology, Faculty of Science, University Putra Malaysia, 43400 Serdang, Selangor, \\ Malaysia \\ 2 Department of Crop Science, Faculty of Agriculture, University Putra Malaysia, 43400 Serdang, \\ Selangor, Malaysia; E-Mail: hawazej@gmail.com
}

* Author to whom correspondence should be addressed; E-Mail: mhafizphd@yahoo.com; Tel.: +6-03-8946-6922/+6-012-372-3585; Fax: +6-03-8943-5973.

Received: 6 June 2013; in revised form: 3 July 2013 / Accepted: 3 July 2013 /

Published: 5 July 2013

\begin{abstract}
An experiment was conducted to investigate and distinguish the relationships in the production of total phenolics, total flavonoids, soluble sugars, $\mathrm{H}_{2} \mathrm{O}_{2}, \mathrm{O}_{2}{ }^{-}$, phenylalanine ammonia lyase (PAL) activity, leaf gas exchange, antioxidant activity, antioxidant enzyme activity [ascorbate peroxidase (APX), catalase (CAT), superoxide dismutase (SOD) and Lipoxygenase inhibitory activity (LOX)] under four levels of foliar abscisic acid (ABA) application $(0,2,4,6 \mu \mathrm{M})$ for 15 weeks in Orthosiphon stamineus Benth. It was found that the production of plant secondary metabolites, soluble sugars, antioxidant activity, PAL activity and LOX inhibitory activity was influenced by foliar application of ABA. As the concentration of $\mathrm{ABA}$ was increased from 0 to $6 \mu \mathrm{M}$ the production of total phenolics, flavonoids, sucrose, $\mathrm{H}_{2} \mathrm{O}_{2}, \mathrm{O}_{2}{ }^{-}$, PAL activity and LOX inhibitory activity was enhanced. It was also observed that the antioxidant capabilities (DPPH and ORAC) were increased. This was followed by increases in production of antioxidant enzymes APX, CAT and SOD. Under high application rates of ABA the net photosynthesis and stomatal conductance was found to be reduced. The production of primary and secondary metabolites displayed a significant positive relationship with $\mathrm{H}_{2} \mathrm{O}_{2}$ (total phenolics, $\mathrm{r}^{2}=0.877$; total flavonoids, $\mathrm{r}^{2}=0.812 ; p \leq 0.05$ ) and $\mathrm{O}_{2}{ }^{-}$(total phenolics, $\mathrm{r}^{2}=0.778$; total flavonoids, $\left.\mathrm{r}^{2}=0.912 ; p \leq 0.05\right)$. This indicated that increased oxidative stress at high application rates of ABA, improved the production of phytochemicals.
\end{abstract}


Keywords: abscisic acid; Orthosiphon stamineus; plant secondary metabolites; photosynthetic performance; antioxidant capabilities; antioxidant enzymes

\section{Introduction}

Orthosiphon stamineus Benth from the Famiy Lamiaceae is locally known as Misai Kucing in Malaysia and Kumis Kuching in Indonesia. This plant is commonly found in tropical countries such as Thailand, Indonesia, Philippines, Brunei and Malaysia. Although found growing in the wild, the plant is also used as an ornamental plant. Orthosiphon stamineus is traditionally used in Southeast Asia as an herbal tea or diuretic to treat kidney disorders, abdominal pains, gout, fever, hypertension, hepatitis, jaundice and diabetes [1]. Moreover, it has been scientifically proven that $O$. stamineus exhibits a range of pharmacological properties such as anti-inflammatory, anti-oxidant, anti-bacterial, anti-angiogenic properties and has hepatoprotective effects [2]. Orthosiphon stamineus contains more than 20 phenolic compounds, including nine caffeic acid derivatives, including rosmarinic acid and 2,3-dicaffeoyltartaric acid, two flavonol glycosides and nine lipophilic flavones [3]. The main components of $O$. stamineus leaves are polyphenols (caffeic acid derivatives and the polymethoxylated flavonoids) [4]. The therapeutic effects of $O$. stamineus have been ascribed mainly to its polyphenols which form the most dominant constituents in the leaf. These constituents have been reported to be effective in reducing oxidative stress by inhibiting the formation of lipid peroxidation products in biological systems [1].

Phenolics and polyphenolics compounds are characterized by an aromatic or phenolics ring structure. These compounds are include the flavonoids, phenolics acids and lignans. Phenolics compounds are located in vacuole, they are found in free from or linked to carbohydrates (glucose, galactose, rhamnose, mannose, rutinose) and tend to be soluble in water or organic solvents [5].These compounds are well recognized to be a good treatment against chronic illnesses such as cancer and cardiovascular diseases [6]. The concentration of phenolic compounds in fruits and vegetables is regulated by genetic, environmental, physiological and chemical factors such as temperature, light, rainfall, soil, chemicals and plant growth regulators [7]. Various agronomic strategies such as alteration of environmental conditions, water management, grafting of plants, application of elicitors, stimulating agents and plant activators have been employed to enhance the biosynthesis of phenolic compounds in fruits and vegetables [8]. One popular strategy is the application of ABA, a plant growth regulator involved in various physiological processes including colour development [9].

Studies have shown that exogenous ABA application affects growth and phytochemical content, and is of particular interest in food and nutritional sciences as it increases the nutritional value of several fruits and vegetables. It has been documented that ABA can induce the expression of antioxidant genes and enhance the capacity of antioxidant defense systems, including enzymatic and non-enzymatic constituents [10]. Meanwhile, since ABA causes oxidative stress in plants, a high concentration of ABA induces excessive generation of active oxygen species (AOS) and leads to oxidative damage in plant cells [11]. In a recent study involving greenhouse red and green leaf lettuces, exogenous ABA application significantly increased the anthocyanin content in red leaf lettuce 
along with the contents of chlorophyll $\mathrm{b}$ and total carotenoids in the green leaf lettuce when compared to the controls [12]. Also, exogenous ABA was found to stimulate anthocyanin biosynthesis and increase the content of phenolic compounds in Noble muscadine grapes [13].

ABA also increased the generation of $\mathrm{H}_{2} \mathrm{O}_{2}$ and $\mathrm{O}_{2}{ }^{-}[14,15]$. The free radicals such as ROS, including hydroxyl radicals, superoxide anions and hydrogen peroxide, play an important role in promoting tissue damage in living organisms. They may lead to cell damage through membrane lipid peroxidation and DNA mutations and as a consequence of that diseases such as cancer may develop [16]. Moreover, ABA is known to enhance activities of antioxidant enzymes such as superoxide dismutase (SOD), ascorbate peroxidase (APX), glutathione reductase (GR), and catalase (CAT) in plant tissues [17-19]. As $\mathrm{H}_{2} \mathrm{O}_{2}$ is relatively stable and diffusible through membranes, it is considered a general signal molecule [20]. Tsai and Kao [21] demonstrated that $\mathrm{H}_{2} \mathrm{O}_{2}$ was involved in $\mathrm{ABA}$-induced activities of APX and GR in rice roots. Water stress-induced ABA accumulation has been shown to trigger increased generation of $\mathrm{H}_{2} \mathrm{O}_{2}$, which in turn led to the up-regulation of secondary metabolites and antioxidant enzyme activities in maize leaves [22,23].

The antioxidant activity of phenolic compounds was found to be mainly due to their scavenging and redox properties through neutralizing and quenching of free radicals. Since the application of ABA has been proven to enhance the production of phytochemicals, It is hypothesized that the use of exogenous ABA might also enhance the production of specific secondary metabolites and increase antioxidant activity in Orthosiphon stamineus. Thus, the primary aim of the present research was to investigate the effects of ABA elicitation on the accumulation of primary and secondary metabolites and antioxidant activity in $O$. stamineus, which would be beneficial to the Malaysian herb industry. The study was also designed to assess the impact of foliar ABA applications on the leaf gas exchange, the secondary metabolic enzymes (PAL), the antioxidative enzymes (SOD, CAT and POD) and lipoxygenase (LOX) inhibitory activity.

\section{Results and Discussion}

\subsection{Total Phenolics and Flavonoids Profiling}

Accumulation of total phenolics and flavonoids in $O$. stamineus were influenced by ABA levels ( $p \leq 0.01$; Table 1). Generally total phenolics content was highest in the leaves followed by roots and stems. As the plants received higher ABA levels $(2>6 \mu \mathrm{M})$ the production of total phenolics and flavonoids was enhanced. The total phenolics content in the leaf (with ABA at $4 \mu \mathrm{M}, 6 \mu \mathrm{M}, 0 \mu \mathrm{M}$ ), roots (with ABA at $6 \mu \mathrm{M}, 4 \mu \mathrm{M}, 2 \mu \mathrm{M}, 0 \mu \mathrm{M}$ ), and stems (with ABA at $6 \mu \mathrm{M}, 4 \mu \mathrm{M}, 2 \mu \mathrm{M}, 0 \mu \mathrm{M}$ ) were $3,6,35,42,44,46,55,120,168,180$, and $218 \%$, respectively. These values were low compared

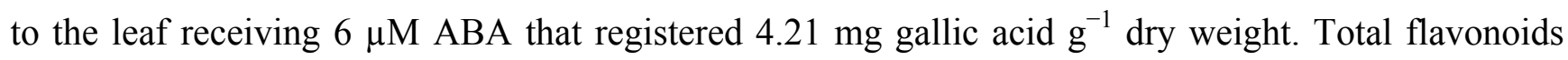
content followed the same trend as total phenolics where the highest total flavonoids was observed in

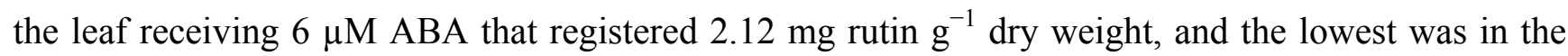
stems with the control treatment $(0 \mu \mathrm{M})$ that contained only $0.52 \mathrm{mg}$ rutin $\mathrm{g}^{-1}$ dry weight. The increase in the production of total phenolics and flavonoids with increasing ABA has also been observed in Vitis rotundifolia [13] and Vitis vinifera [24]. Wang et al. [25] observed that as the level of foliar application of ABA increased, the production of soluble sugar was enhanced in Atractylodes 
macrocephala. Carbohydrates are basic compounds required to produce phenolic compounds through the shikimic acid pathway where extra carbohydrates derived from glycolysis and the pentose phosphate pathway are converted into aromatic amino acids. Previous studies by Shui et al. [26] showed that an increase in secondary metabolites was related to the balance between carbohydrate source and sink; the greater the source-sink ratio, the greater the production of secondary metabolites that might occur. This was also reported by Guo et al. [27] that found an increase in sucrose content corresponding to the enhanced production of ascorbic acid, glucosinolates, sulforaphane, anthocyanins, total phenolics and increased antioxidative activities in broccoli sprouts. This was supported by source-sink hypotheses (carbon nutrient balance hypothesis) [28] and growth-differentiation balance hypothesis [29] that assume that increase in carbon accessibility that is accumulated in total non-structurable carbohydrate (TNC) would increased the production of carbon based secondary metabolites (total phenolics and flavonoids) when the provided carbon amounts exceed growth requirements [30]. This suggests that the increase in the production of total non-structural carbohydrates might up-regulate the production of total phenolics and flavonoids with the application of ABA in the current study. This fact is supported by the high significant correlation coefficients of total phenolics $\left(\mathrm{r}^{2}=0.971 ; p \leq 0.05\right)$ and total flavonoids $\left(\mathrm{r}^{2}=0.953 ; p \leq 0.05\right)$ with soluble sugars (Table 2). The present results indicate that exogenous application of ABA can enhance the production of carbon based secondary metabolites like total phenolics and flavonoids. In previous studies the application of abscicic acid have been shown to improve the production of tanshinone in Salvia miltiorrhiza [31], chlorogenic acid in Phragmites communis [32], and terpenoids in Cannabis sativa [33], thus indicating the importance of ABA in increasing the production of secondary metabolites in plants.

Table 1. Impact of abscisic acid on total phenolics, flavonoids and soluble sugars produced in different parts of Orthosiphon stamineus.

\begin{tabular}{|c|c|c|c|c|}
\hline $\mathbf{A B A}(\mu \mathrm{M})$ & Parts & $\begin{array}{l}\text { Total Phenolics } \\
\text { (mg g } \mathrm{g}^{-1} \text { gallic acid } \\
\text { dry weight) }\end{array}$ & $\begin{array}{c}\text { Total Flavonoids } \\
\text { ( } \mathrm{mg} \mathrm{g}^{-1} \text { rutin } \\
\text { dry weight) }\end{array}$ & $\begin{array}{c}\text { Soluble sugar } \\
\left(\mathrm{mg} \mathrm{g}^{-1} \text { sucrose }\right. \\
\text { dry weight) }\end{array}$ \\
\hline \multirow{3}{*}{0} & Leaves & $3.11 \pm 0.27^{c}$ & $1.47 \pm 0.21^{c}$ & $79.12 \pm 11.21^{d}$ \\
\hline & Stems & $1.32 \pm 0.02^{1}$ & $0.52 \pm 0.02^{\mathrm{g}}$ & $40.23 \pm 8.98^{1}$ \\
\hline & Roots & $2.71 \pm 1.24^{\mathrm{e}}$ & $1.21 \pm 0.34^{\mathrm{k}}$ & $62.18 \pm 12.12^{h}$ \\
\hline \multirow{3}{*}{2} & Leaves & $3.98 \pm 0.34^{b}$ & $1.72 \pm 0.56^{\mathrm{b}}$ & $88.21 \pm 9.76^{\mathrm{c}}$ \\
\hline & Stems & $1.50 \pm 0.04^{\mathrm{h}}$ & $0.76 \pm 0.34^{f}$ & $47.21 \pm 11.21^{\mathrm{k}}$ \\
\hline & Roots & $2.87 \pm 0.45^{\mathrm{d}}$ & $1.18 \pm 0.12^{\mathrm{j}}$ & $68.21 \pm 12.12^{g}$ \\
\hline \multirow{3}{*}{4} & Leaves & $4.10 \pm 0.21^{\mathrm{ab}}$ & $1.98 \pm 0.32^{a b}$ & $90.17 \pm 10.76^{b c}$ \\
\hline & Stems & $1.57 \pm 0.05^{\mathrm{g}}$ & $0.86 \pm 0.12^{\mathrm{e}}$ & $50.11 \pm 5.67^{j}$ \\
\hline & Roots & $2.92 \pm 0.03^{\mathrm{d}}$ & $1.27 \pm 0.32^{i}$ & $70.82 \pm 5.88^{f}$ \\
\hline \multirow{3}{*}{6} & Leaves & $4.21 \pm 0.02^{\mathrm{a}}$ & $2.12 \pm 0.04^{\mathrm{a}}$ & $98.12 \pm 7.98^{a}$ \\
\hline & Stems & $1.92 \pm 0.21^{\mathrm{f}}$ & $0.97 \pm 0.08^{\mathrm{d}}$ & $57.12 \pm 12.12^{1}$ \\
\hline & Roots & $2.97 \pm 0.11^{\mathrm{de}}$ & $1.46 \pm 0.12^{h}$ & $76.21 \pm 10.12^{e}$ \\
\hline
\end{tabular}

All results are expressed as means \pm standard error of mean (SEM). $\mathrm{N}=40$. Means within columns with the same alphabets are not significantly different at $p \leq 0.05$. 
Table 2. Pearson's correlation coefficients between total phenolics and total flavonoids with all parameters measured in the study.

\begin{tabular}{lcc}
\hline \multirow{2}{*}{ Parameters } & \multicolumn{2}{c}{ Pearson's correlation coefficient $\left(\mathbf{R}^{2}\right)$} \\
\cline { 2 - 3 } & Total phenolics & Total flavonoids \\
\hline 1. Soluble sugar & $0.971 *$ & $0.973 *$ \\
2. $\mathrm{H}_{2} \mathrm{O}_{2}$ & $0.877 *$ & $0.812 *$ \\
3. $\mathrm{O}_{2}$ & $0.778 *$ & $0.912 *$ \\
4. PAL activity & $0.923 *$ & $0.901 *$ \\
5. APX & $0.781 *$ & $0.822 * *$ \\
6. SOD & $0.845 *$ & $0.816 *$ \\
7. CAT & $0.912 *$ & $0.832 *$ \\
8. ORAC & $0.904 *$ & $0.956 *$ \\
9. DPPH & $0.781 *$ & $0.889 *$ \\
10. Net Photosynthesis & $-0.871 *$ & $-0.921 *$ \\
11. Stomata conductance & $-0.881 * *$ & $-0.824 *$ \\
12. LOX & $0.951 *$ & $0.923 *$ \\
\hline \multicolumn{2}{c}{$* * *$ significant at $p \leq 0.05$ and 0.01, respectively. }
\end{tabular}

\subsection{Soluble Sugar Profiling}

The profiling of soluble sugar was influenced by ABA levels applied to Orthosiphon stamineus $(p \leq 0.01)$. The accumulation of carbohydrates in different parts of the plant followed a descending order with leaf $>$ root $>$ stem. As ABA levels increased, the concentration of soluble sugar increased (Table 1). It was found that, the concentration of sucrose and starch registered the lowest values with $0 \mu \mathrm{M}$ ABA compared to the other treatments. In the leaves, the $0,2,4$ and $6 \mu \mathrm{M} \mathrm{ABA}$ treatments resulted in the production of $79.12,88.21,90.17$ and $98.12 \mathrm{mg}$ sucrose $\mathrm{g}^{-1}$ dry weight, respectively. The results indicate that applications of $\mathrm{ABA}$ until $6 \mu \mathrm{M}$ was able to enhance the soluble sugar content. Jaafar [34] had also observed an increase in soluble sugar content in Capsicum annum due to accumulation of ABA in the plant. Similar responses were also observed in maize [35] and cucumber [36] with foliar applications of ABA. Structural carbohydrates are the basic compounds required to produce carbon-based secondary metabolites in the shikimic acid pathway [37]. Ibrahim and Jaafar [38] found that increase in the production of total phenolics and flavonoids in the medicinal plant Labisia pumila was due to an increase in the production of carbohydrate content. Jones and Hartley [39] proposed that the increase in phenolics and flavonoids production was related to the balance between carbohydrate source and sink, the greater the source-to-sink ratio the greater would be the production of plant secondary metabolites.

\subsection{Antioxidant Content of $\mathrm{H}_{2} \mathrm{O}_{2}$ and $\mathrm{O}_{2}^{-}$}

Assay of $\mathrm{H}_{2} \mathrm{O}_{2}$ and $\mathrm{O}_{2}{ }^{-}$was influenced by the ABA treatments $(p \leq 0.01$; Table 3$)$. With $\mathrm{H}_{2} \mathrm{O}_{2}$ the highest antioxidant activity of $2.81 \mu \mathrm{mol} \mathrm{TE} / \mathrm{g}$ dry weight was recorded in the leaf receiving $6 \mu \mathrm{M}$ ABA. This was followed by the leaf receiving $4 \mu \mathrm{M} \mathrm{ABA}\left(2.60 \mu \mathrm{mol} \mathrm{TE} \mathrm{g}^{-1}\right.$ dry weight $), 2 \mu \mathrm{M} \mathrm{ABA}$ (2.43 $\mu \mathrm{mol} \mathrm{TE} \mathrm{g}^{-1}$ dry weight), and $0 \mu \mathrm{M} \mathrm{ABA}\left(2.19 \mu \mathrm{mol} \mathrm{TE} \mathrm{g}^{-1}\right.$ dry weight $)$, the roots receiving $6 \mu \mathrm{M}$ ABA $\left(1.78 \mu \mathrm{mol} \mathrm{TE} \mathrm{g}^{-1}\right.$ dry weight $), 4 \mu \mathrm{M}$ ABA $\left(1.66 \mu \mathrm{mol} \mathrm{TE} \mathrm{g}^{-1}\right.$ dry weight $), 2 \mu \mathrm{M}$ ABA 
(1.52 $\mu \mathrm{mol} \mathrm{TE} \mathrm{g}^{-1}$ dry weight), and $0 \mu \mathrm{M}$ ABA $\left(1.32 \mu \mathrm{mol} \mathrm{TE} \mathrm{g}^{-1}\right.$ dry weight), and stems receiving $6 \mu \mathrm{M}$ ABA $\left(0.91 \mu \mathrm{mol} \mathrm{TE} \mathrm{g}^{-1}\right.$ dry weight $), 4 \mu \mathrm{M}$ ABA $\left(0.90 \mu \mathrm{mol} \mathrm{TE} \mathrm{g}^{-1}\right.$ dry weight $), 2 \mu \mathrm{M}$ ABA $\left(0.78 \mu \mathrm{mol} \mathrm{TE} \mathrm{g}^{-1}\right.$ dry weight $)$ and $0 \mu \mathrm{M} \mathrm{ABA}\left(0.67 \mu \mathrm{mol} \mathrm{TE} \mathrm{g}^{-1}\right.$ dry weight $)$. With $\mathrm{O}_{2}^{-}$, the assay showed a similar pattern as $\mathrm{H}_{2} \mathrm{O}_{2}$. The data indicated that $O$. stamineus sprayed with $\mathrm{ABA}$ had high oxidative stress. There is abundant evidence to show that ROS especially $\mathrm{H}_{2} \mathrm{O}_{2}$ and $\mathrm{O}_{2}{ }^{-}$are involved in the cellular signaling process as secondary messengers [40]. Thus, ABA mediated metabolic changes lead to an increase in endogenous ROS levels, which in turn induces antioxidative gene expression [41]. Correlation analyses shows that the increase in antioxidative properties might be up-regulated by the increase in total phenolics and flavonoids in plants receiving foliar applications of ABA (Table 3). All antioxidant properties were observed to have strong significant positive correlations with total phenolics $\left(\mathrm{r}^{2}, \mathrm{H}_{2} \mathrm{O}_{2}=0.9111 ; \mathrm{O}_{2}{ }^{-}=0.887 ; p \leq 0.05\right)$ and flavonoids $\left(\mathrm{r}^{2}, \mathrm{H}_{2} \mathrm{O}_{2}=0.9111 ; \mathrm{O}_{2}{ }^{-}=0.887\right.$; $p \leq 0.05$; Table 2). This implies that the increase in total phenolics and flavonoids with foliar ABA applications are associated with increased antioxidant capacities that allow quenching of the excited state of active oxygen species [42-44].

Table 3. Impact of abscisic acid levels on $\mathrm{H}_{2} \mathrm{O}_{2}, \mathrm{O}_{2}{ }^{-}$and $\mathrm{PAL}$ activity in different parts of Orthosiphon stamineus.

\begin{tabular}{|c|c|c|c|c|}
\hline $\mathbf{A B A}(\mu \mathrm{M})$ & Parts & $\begin{array}{c}\mathrm{H}_{2} \mathrm{O}_{2} \\
\left(\mu \mathrm{mol} \mathrm{g}^{-1}\right. \\
\text { fresh weight })\end{array}$ & $\begin{array}{c}\mathrm{O}_{2}^{-} \\
\left(\mu \mathrm{mol} \mathrm{g^{-1 }} \mathrm{dry}\right. \\
\left.\text { weight } \mathrm{min}^{-1}\right) \\
\end{array}$ & $\begin{array}{c}\text { PAL Activity } \\
(\mathrm{nm} \text { transcinnamic } \\
\left.\mathrm{mg}^{-1} \text { protein }^{-1} \mathrm{~h}^{-1}\right)\end{array}$ \\
\hline \multirow{3}{*}{0} & Leaves & $2.19 \pm 0.34^{\mathrm{d}}$ & $1.09 \pm 0.02^{\mathrm{d}}$ & $9.21 \pm 0.62^{d}$ \\
\hline & Stems & $0.67 \pm 0.21^{\mathrm{k}}$ & $0.32 \pm 0.23^{j}$ & $2.08 \pm 0.23^{1}$ \\
\hline & Roots & $1.32 \pm 0.23^{\mathrm{h}}$ & $0.66 \pm 0.45^{\mathrm{g}}$ & $5.02 \pm 0.15^{\mathrm{h}}$ \\
\hline \multirow{3}{*}{2} & Leaves & $2.43 \pm 0.31^{\mathrm{c}}$ & $1.17 \pm 0.32^{\mathrm{c}}$ & $10.16 \pm 0.82^{c}$ \\
\hline & Stems & $0.78 \pm 0.03^{\mathrm{k}}$ & $0.44 \pm 0.12^{\mathrm{i}}$ & $2.17 \pm 0.12^{k}$ \\
\hline & Roots & $1.52 \pm 0.34^{\mathrm{g}}$ & $0.72 \pm 0.02^{f}$ & $6.23 \pm 0.32^{g}$ \\
\hline \multirow{3}{*}{4} & Leaves & $2.60 \pm 0.06^{\mathrm{b}}$ & $1.23 \pm 0.12^{b}$ & $13.11 \pm 2.13^{b}$ \\
\hline & Stems & $0.90 \pm 0.02^{j}$ & $0.56 \pm 0.13^{h}$ & $3.21 \pm 0.19^{\mathrm{j}}$ \\
\hline & Roots & $1.66 \pm 0.21^{\mathrm{f}}$ & $0.87 \pm 0.01^{\mathrm{e}}$ & $7.11 \pm 0.34^{f}$ \\
\hline \multirow{3}{*}{6} & Leaves & $2.81 \pm 0.06^{\mathrm{a}}$ & $1.57 \pm 0.21^{\mathrm{a}}$ & $17.21 \pm 1.21^{\mathrm{a}}$ \\
\hline & Stems & $0.91 \pm 0.12^{\mathrm{i}}$ & $0.57 \pm 0.11^{\mathrm{h}}$ & $4.11 \pm 0.61^{\mathrm{i}}$ \\
\hline & Roots & $1.78 \pm 0.02^{\mathrm{e}}$ & $0.91 \pm 0.04^{\mathrm{e}}$ & $8.81 \pm 0.54^{\mathrm{e}}$ \\
\hline
\end{tabular}

Results are presented as means \pm standard error of mean $(\mathrm{SEM}) . \mathrm{N}=40$. Means within columns with the same alphabets are not significantly different at $p \leq 0.05$.

\subsection{Phenyl Alanine Ammonia Lyase (PAL) Activity}

In general, the PAL activity in $O$. stamineus was found to be highest in leaves followed by roots and stems. Also, as the concentration of ABA increased from 2 to $6 \mu \mathrm{M}$ the PAL activity was found to increase (Table 4). In leaves the application of $6 \mu \mathrm{M}$ ABA resulted in the highest PAL activity (17.21 nM transcinnamic $\mathrm{mg}^{-1}$ protein $\mathrm{h}^{-1}$ ), whilst the lowest was observed in stems receiving $0 \mu \mathrm{M}$ ABA which registered $2.08 \mathrm{nM}$ transcinnamic $\mathrm{mg}^{-1}$ protein $\mathrm{h}^{-1}$. An increase in the production of total phenolics and flavonoids in the present work is attributed to an increase in PAL activity under high concentrations of ABA. Correlation analysis showed that PAL activity had significant positive 
relationships with total phenolics $\left(\mathrm{r}^{2}=0.923 ; p \leq 0.05\right)$ and flavonoids $\left(\mathrm{r}^{2}=0.901 ; p \leq 0.05\right)$ which indicate an up-regulation of secondary metabolite production with increased PAL activity (Table 2). The present results also indicate that under high application rates of foliar ABA, the activity of phenylalanine is increased, which simultaneously enhanced the production of secondary metabolites [45]. The increase in PAL activity with increase in ABA levels was also observed by Duan et al. [45] in Cynomorium songaricum and Poceicha et al. [46] in Microdochium nivale. These results suggest that up-regulation of production of secondary metabolites in $O$. stamineus under high levels of ABA is attributed to the increase in PAL activity.

\subsection{Antioxidant Enzyme Activities}

Activities of the antioxidant enzymes ascorbate peroxidase (APX), catalase (CAT) and superoxide dismutase (SOD) were significantly $(p \leq 0.05)$ affected by ABA application (Table 4$)$. The APX, CAT and SOD activities were found to be highest at the maximum ABA application of $6 \mu \mathrm{M}$ ABA.

Table 4. Impact of abscisic acid levels on antioxidant enzyme activity in different parts of Orthosiphon stamineus.

\begin{tabular}{|c|c|c|c|c|}
\hline $\mathbf{A B A}(\mu \mathrm{M})$ & Parts & $\begin{array}{l}\text { Ascorbate peroxidase } \\
\text { activity (APX; } \\
\text { mg protein }^{-1} \text { min }^{-1} \text { ) }\end{array}$ & $\begin{array}{c}\text { Superoxide dismutase } \\
\text { activity (SOD } \\
\operatorname{mg~protein~}^{-1} \min ^{-1} \text { ) }\end{array}$ & $\begin{array}{l}\text { Catalase activity } \\
(\mathrm{CAT} ; \mu \mathrm{mol} \mathrm{mg} \\
\left.\text { protein }^{-1} \mathrm{~min}^{-1}\right)\end{array}$ \\
\hline \multirow{3}{*}{0} & Leaves & $15.23 \pm 2.34^{d}$ & $4.62 \pm 0.11^{\mathrm{d}}$ & $19.21 \pm 1.27^{\mathrm{d}}$ \\
\hline & Stems & $6.12 \pm 0.81^{\mathrm{k}}$ & $1.34 \pm 0.01^{1}$ & $6.66 \pm 2.11^{1}$ \\
\hline & Roots & $10.11 \pm 0.03^{h}$ & $2.98 \pm 0.41^{h}$ & $12.17 \pm 0.97^{\mathrm{h}}$ \\
\hline \multirow{3}{*}{2} & Leaves & $17.11 \pm 0.51^{\mathrm{c}}$ & $4.82 \pm 0.21^{\mathrm{c}}$ & $20.12 \pm 0.82^{c}$ \\
\hline & Stems & $6.11 \pm 0.53^{\mathrm{k}}$ & $1.52 \pm 0.36^{\mathrm{k}}$ & $8.27 \pm 0.78^{\mathrm{k}}$ \\
\hline & Roots & $11.27 \pm 0.14^{\mathrm{g}}$ & $3.62 \pm 0.15^{\mathrm{g}}$ & $13.24 \pm 0.11^{\mathrm{g}}$ \\
\hline \multirow{3}{*}{4} & Leaves & $19.71 \pm 0.16^{b}$ & $5.01 \pm 0.17^{b}$ & $23.17 \pm 0.78^{b}$ \\
\hline & Stems & $7.23 \pm 0.42^{j}$ & $1.71 \pm 2.11^{\mathrm{j}}$ & $9.23 \pm 1.19^{j}$ \\
\hline & Roots & $13.22 \pm 0.31^{\mathrm{f}}$ & $3.89 \pm 1.02^{f}$ & $16.59 \pm 0.89^{f}$ \\
\hline \multirow{3}{*}{6} & Leaves & $21.62 \pm 0.26^{\mathrm{a}}$ & $5.27 \pm 0.81^{\mathrm{a}}$ & $25.12 \pm 1.21^{\mathrm{a}}$ \\
\hline & Stems & $9.12 \pm 0.98^{i}$ & $1.76 \pm 0.92^{\mathrm{i}}$ & $10.24 \pm 2.17^{\mathrm{i}}$ \\
\hline & Roots & $14.21 \pm 1.32^{\mathrm{e}}$ & $4.02 \pm 1.24^{\mathrm{e}}$ & $17.21 \pm 0.98^{\mathrm{e}}$ \\
\hline
\end{tabular}

All results are presented as means \pm standard error of mean (SEM). $N=40$. Means within columns with the same alphabets are not significantly different at $p \leq 0.05$.

These activities are an indication that ABA application at high doses can enhance the oxidative stress in O. stamineus seedlings. The increase in APX, CAT and SOD activities had a positive significant correlation with production of total phenolics and flavonoids, which indicates that an increase in oxidative stress can enhance production of secondary metabolites in $O$. stamineus seedlings under high foliar ABA applications. Induction of antioxidant enzymes was reported to be a general strategy adopted by plants to overcome oxidative stresses. The APX, CAT and SOD function as effective quenchers for ROS [47]. CAT plays an essential role in scavenging from $\mathrm{H}_{2} \mathrm{O}_{2}$ toxicity. The combined action of CAT and SOD converts the $\mathrm{O}^{2-}$ and $\mathrm{H}_{2} \mathrm{O}_{2}$ to water and molecular oxygen $\left(\mathrm{O}_{2}\right)$, thus preventing cellular damage under unfavorable conditions [48]. The present study suggests that 
ABA application caused oxidative stress in O. stimaneus, and at the same time enhanced the production of secondary metabolites [49]. The study by Homa and Elham [50] had shown that production of APX, CAT and SOD was enhanced in bean seedlings after ABA application, and was followed by significant increases in $\mathrm{H}_{2} \mathrm{O}_{2}$. Similar observations were made in the present study where higher levels of ABA enhanced the production of antioxidant enzymes and were simultaneously followed by an increase in generation of $\mathrm{O}_{2}$ and $\mathrm{H}_{2} \mathrm{O}_{2}$.

\subsection{1,1-Diphenyl-2-picryl-hydrazyl (DPPH) and Oxygen Radical Absorbance Capacity (ORAC) Assay}

The purple colored DPPH is a stable free radical, which can be reduced to $\alpha, \alpha$-diphenyl- $\beta$ picryhydrazine (yellow colored) when reacted with antioxidant. The latter interrupts the free radical chain oxidation by donating hydrogen from the hydroxyl group to form a stable end product that does not initiate or propagate further oxidation of lipids [51]. Generally, DPPH antioxidant activity in $O$. staminaeus was found to be the highest on the underside of leaves, followed by the roots and the stems at all levels of ABA application (Table 5).

Table 5. Impact of abscisic acid levels on antioxidant capacities in different parts of Orthosiphon stamineus.

\begin{tabular}{|c|c|c|c|}
\hline $\mathbf{A B A}(\mu \mathrm{M})$ & Parts & $\begin{array}{c}\text { ORAC } \\
\left(\mu \mathrm{mol} \text { Trolox equivalent } \mathrm{g}^{-1}\right)\end{array}$ & $\begin{array}{c}\text { DPPH } \\
\left(\mu \mathrm{mol} \text { Trolox equivalent } \mathrm{g}^{-1}\right)\end{array}$ \\
\hline \multirow{3}{*}{0} & Leaves & $65.21 \pm 2.41^{\mathrm{d}}$ & $20.19 \pm 9.02^{d}$ \\
\hline & Stems & $35.67 \pm 0.21^{\mathrm{i}}$ & $7.72 \pm 2.32^{j}$ \\
\hline & Roots & $51.07 \pm 2.23^{\mathrm{g}}$ & $13.66 \pm 6.45^{h}$ \\
\hline \multirow{3}{*}{2} & Leaves & $69.31 \pm 10.31^{\mathrm{c}}$ & $25.17 \pm 8.32^{c}$ \\
\hline & Stems & $37.78 \pm 9.03^{k}$ & $9.44 \pm 7.12^{\mathrm{k}}$ \\
\hline & Roots & $55.02 \pm 0.34^{1}$ & $15.72 \pm 3.02^{\mathrm{g}}$ \\
\hline \multirow{3}{*}{4} & Leaves & $70.60 \pm 8.96^{b}$ & $27.84 \pm 9.12^{b}$ \\
\hline & Stems & $40.90 \pm 11.02^{h}$ & $10.23 \pm 8.13^{i}$ \\
\hline & Roots & $57.21 \pm 10.21^{\mathrm{f}}$ & $16.21 \pm 2.21^{\mathrm{f}}$ \\
\hline \multirow{3}{*}{6} & Leaves & $77.81 \pm 0.06^{\mathrm{a}}$ & $31.57 \pm 9.21^{\mathrm{a}}$ \\
\hline & Stems & $45.21 \pm 0.121^{\mathrm{g}}$ & $11.01 \pm 2.11^{\mathrm{h}}$ \\
\hline & Roots & $60.23 \pm 8.02^{e}$ & $17.81 \pm 2.04^{\mathrm{e}}$ \\
\hline
\end{tabular}

All results are presented as means \pm standard error of mean $(\mathrm{SEM}) . \mathrm{N}=40$. Means within columns with the same alphabets are not significantly different at $p \leq 0.05$.

The DPPH antioxidant activity at $6 \mu \mathrm{M}$ ABA was the highest (17.81-31.57 $\left.\mu \mathrm{mol} \mathrm{TE} \mathrm{g}^{-1}\right)$, followed by the $4 \mu \mathrm{M}$ ABA (15.72-25.17 $\left.\mu \mathrm{mol} \mathrm{TE} \mathrm{g}^{-1}\right), 2 \mu \mathrm{M}$ ABA (16.21-27.84 $\left.\mu \mathrm{mol} \mathrm{TE} \mathrm{g}^{-1}\right)$ and the lowest in $0 \mu \mathrm{M}$ ABA (13.66-20.19 $\mu \mathrm{mol} \mathrm{TE} \mathrm{g}^{-1}$ ). The ORAC assay also showed the same trend as with DPPH. The antioxidant capacity measured by ORAC was much higher than DPPH. This was because ORAC and DPPH methods used different chemistry and mechanisms to measure antioxidant capacity. The ORAC applies a competitive reaction scheme, in which the substrate and the antioxidant compete for thermally generated peroxyl radicals through the decomposition of azo compounds $[43,52]$. However, the DPPH assay measures the capacity of an antioxidant in the reduction of an oxidant, which changes colour when reduced. The lower values for DPPH is attributed to the fact that those 
antioxidants that react quickly with peroxy radicals will react even slower or may not react with DPPH due to steric inaccessibility. The present results showed that the application of ABA can enhance the antioxidant capacity of Orthosiphon stamineus [53]. The enhancement of antioxidant capacity with application of $\mathrm{ABA}$ was due to enhancement of total phenolics and flavonoids with the application of ABA. From the correlation analysis (Table 2), it was apparent that total phenolics and flavonoids had significant positive relationships with DPPH and ORAC assays, implying that high antioxidant power with the application of $\mathrm{ABA}$ might have contributed to the higher content of gallic acid and rutin in the plant extract. Previous studies have shown that a combination of polyphenolic compounds produced a synergistic effect on DPPH and ORAC [54,55].

\subsection{Leaf Gas Exchange}

It is generally known that the accumulation of ABA can reduce stomatal conductance and net photosynthesis of plants. In the present study, it was observed that as ABA was increased from 2 to 6 $\mu \mathrm{M}$ the stomatal conductance and net photosynthesis showed a decreasing trend. The net photosynthesis with the $6 \mu \mathrm{M}$ ABA treatment was $1.41 \mu \mathrm{mol} \mathrm{m} \mathrm{m}^{-2} \mathrm{~s}^{-1}$. This was 70,211 and $451 \%$ lower compared to the treatments with 4,2 and $0 \mu \mathrm{M}$ ABA, respectively. The correlation analysis found that net photosynthesis had a significant negative relationship with total phenolics $\left(\mathrm{r}^{2}=-0.870\right.$; $p \leq 0.05$ ) and flavonoids $\left(\mathrm{r}^{2}=-0.921 ; p \leq 0.05\right.$ ) (Table 2$)$. The present study indicates that with the application of $\mathrm{ABA}$, the down-regulation of photosynthesis up-regulates the production of secondary metabolites in O. stamineus seedlings (Figure 1).

Figure 1. Effect of different ABA levels on leaf gas exchange in leaves of Orthosiphon Stamineus $[\mathrm{N}=40$; Bars represent standard error of differences between means (SEM)].

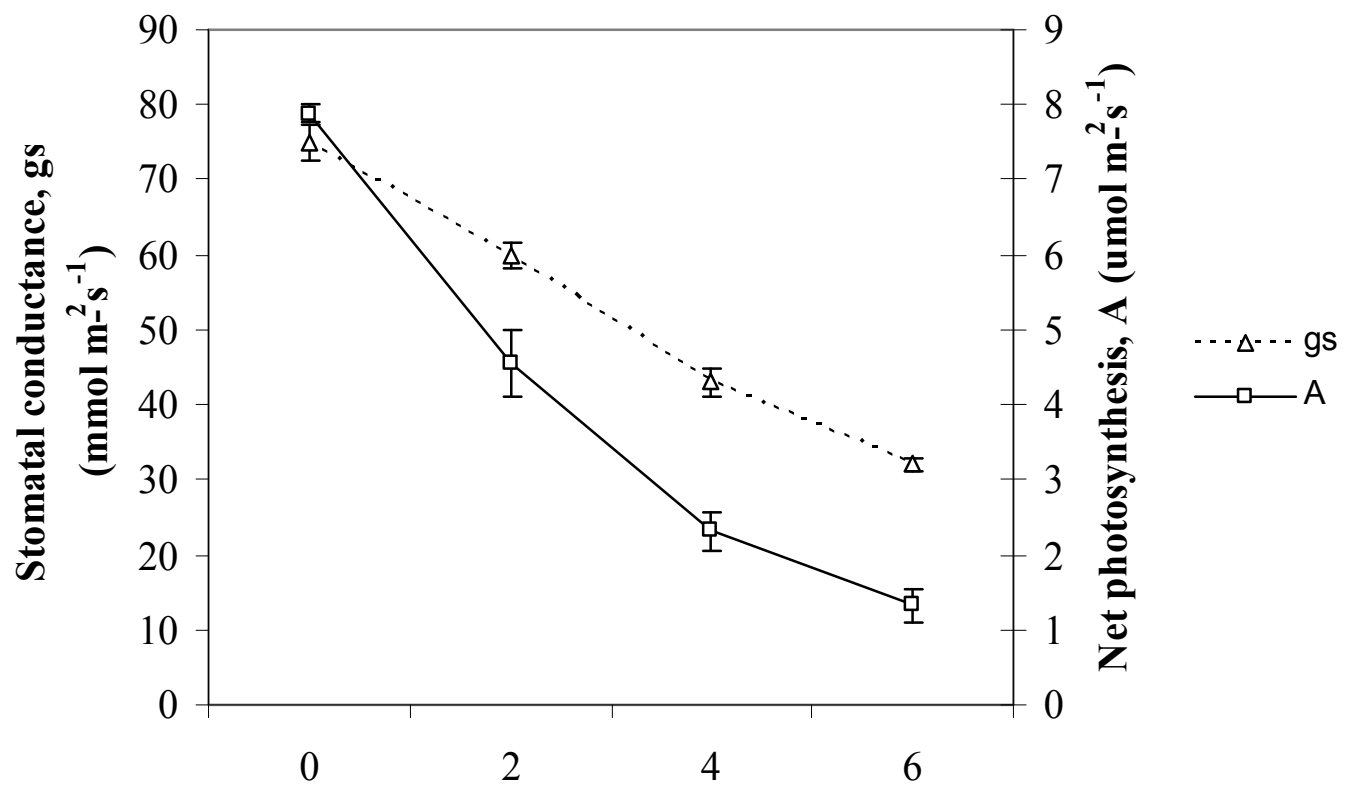

ABA conce ntrations $(\mu M)$

This is attributed to the accumulation of ROS in O. stamineus seedlings. According to Bowler [56] ABA induced stomatal closure can cause a reduction in the availability of $\mathrm{CO}_{2}$ for photosynthesis, which may lead to the generation of ROS from the misdirection of electrons in the photosystem. 


\subsection{Lipoxygenase (LOX) Inhibitory Activity}

LOX catalyzes dioxygenation of polyunsaturated fatty acids to yield cis, trans-conjugated diene droperoxides. LOXs are key enzymes in the biosynthesis of leukotrienes from fatty acids producing active lipid metabolites [57]. LOX is involved in provoking several inflammation-related diseases such as arthritis, asthma, cardiovascular, cancer and allergic diseases [58]. For this reason, targeting inhibitors of LOX is a promising therapeutic target for treating a wide spectrum of human diseases. Results of LOX inhibitory activity $\left(\mathrm{IC}_{50}\right)$ are presented in Figure 2. Plants treated with $6 \mu \mathrm{M} \mathrm{ABA}$ extract showed the strongest ability $(\mathrm{p}<0.05)$ to inhibit LOX activity $\left(\mathrm{IC}_{50}=19.17 \mu \mathrm{g} \mathrm{mL}^{-1}\right)$ compared to the $4 \mu \mathrm{M}$ ABA extract $\left(\mathrm{IC}_{50}=23.31 \mu \mathrm{g} \mathrm{mL}^{-1}\right), 2 \mu \mathrm{M} \mathrm{ABA}$ extract $\left(\mathrm{IC}_{50}=41.61 \mu \mathrm{g} \mathrm{mL}^{-1}\right)$ and the $0 \mu \mathrm{M}$ ABA extract $\left(\mathrm{IC}_{50}=78.61 \mu \mathrm{g} \mathrm{mL} \mathrm{m}^{-1}\right)$. However, both crude ethanol extracts possessed significantly lower $(\mathrm{p}<0.05)$ LOX inhibitory activity than that of the NDGA positive standard $\left(\mathrm{IC}_{50}=4.41 \mu \mathrm{g} \mathrm{mL}^{-1}\right)$. The LOX inhibition in O. stamineus was higher than those for other common plants such as Thespesia lampas $\left(600 \mu \mathrm{g} \mathrm{mL}^{-1}\right)$ [59]. The current results suggest that $O$. stamineus treated with ABA had potentially high anti-LOX activity, which might be related to the high secondary metabolites content and antioxidant property of the extract [60,61].

Figure 2. Effect of ABA levels on lipoxygenase inhibitory activity of $O$. stamineus Benth [expressed as $\mathrm{IC}_{50}\left(\mu \mathrm{g} \mathrm{mL} \mathrm{m}^{-1}\right)$; Nordihydroguaiaretic acid (NDGA) was used as a positive standard].

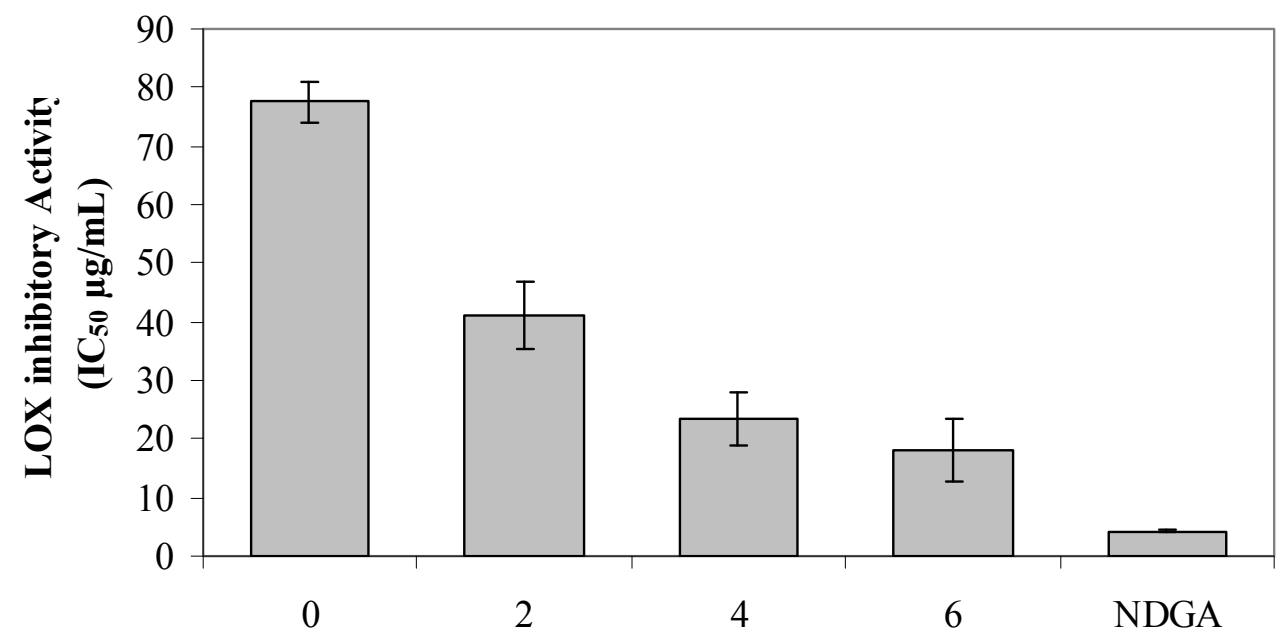

ABA concentrations $(\boldsymbol{\mu M})$

\section{Experimental}

\subsection{Plant Materials and Maintenance}

The experiment was carried out in a glasshouse at the Faculty of Agriculture Glasshouse Complex, Universiti Putra Malaysia (longitude $101^{\circ} 44^{\prime} \mathrm{N}$ and latitude $2^{\circ} 58^{\prime} \mathrm{S}, 68 \mathrm{~m}$ above sea level) with a mean atmospheric pressure of $1.013 \mathrm{kPa}$. Stem cuttings of $O$. staminaes were propagated for two weeks in small pots and then transferred to white polyethylene bags filled with a soilless mixture of burnt rice husk and coco peat (ratio 3:1). The light intensity inside the glasshouse was from 225-1450 $\mu \mathrm{mol} \mathrm{m} \mathrm{m}^{-2} \mathrm{~s}^{-1}$. Before the experiment initiated, preliminary experiment were conducted to 
determine the optimum concentration of ABA to be applied to O. staminaes. The concentration of ABA from $0-12 \mu \mathrm{M}$ were used. Among the treatments, the application of ABA below $7 \mu \mathrm{M}$ have shown to significantly increased the plant dry weight and leaf number, however concentration more than $7 \mu \mathrm{M}$ have shown to reduce the plant dry weight and leaf number. Hence the concentration $<7$ $\mu \mathrm{M}$ ABA were used in this study. The exogenous ABA treatments ( \pm cis/trans ABA; Sigma, St Louis, MO, USA) were applied by spraying the whole plants with $10 \mathrm{~mL}$ of $0,2,4$ or $6 \mu \mathrm{M}$ ABA per day. Abscisic acid was dissolved in water containing $315 \mu \mathrm{L} \mathrm{L}^{-1}$ Tween 20 as wetting agent [55]. The control solution $(0 \mu \mathrm{M} \mathrm{ABA})$ contained water with Tween 20 . The experiment was based on a randomized complete block design with four replicates. The factor was four levels of ABA treatments $(0,2,4,6 \mu \mathrm{M})$. Each combination treatment consisted of 10 plants totaling a sum of 160 plants in the experiment. Plants were harvested for analysis at 12 weeks after planting, this is due this the plant was usually harvested three months after planting. The microclimatic conditions under the glasshouse are presented in Table 6.

Table 6. Microclimatic condition under the research area during 12 weeks of experiments.

\begin{tabular}{cc}
\hline Microclimate parameters & Quantification \\
\hline Relative Humidity & $56.14-65.32 \%$ \\
Light intensity & $225-1450 \mu \mathrm{mol} \mathrm{m}^{-2} \mathrm{~s}^{-1}$ \\
Day temperature & $27-31^{\circ} \mathrm{C}$ \\
Night temperature & $18-22^{\circ} \mathrm{C}$ \\
Ambient $\mathrm{CO}_{2}$ & $372.81 \mu \mathrm{mol} \mathrm{mol}^{-1}$ \\
\hline
\end{tabular}

\subsection{Determination of Total Phenolics and Flavonoids}

The method used for extraction and quantification of total phenolics and flavonoids was as described by Ibrahim and Jaafar [62]. Ground tissue samples $(0.1 \mathrm{~g})$ were extracted with $80 \%$ ethanol $(10 \mathrm{~mL})$ on an orbital shaker for $120 \mathrm{~min}$ at $50^{\circ} \mathrm{C}$. The mixture was subsequently filtered (Whatman ${ }^{\mathrm{TM}}$ No.1), and the filtrate was used for the quantification of total phenolics and total flavonoids. Folin-Ciocalteu reagent (diluted 10-fold) was used to determine the total phenolics content of the leaf samples. Two hundred $\mu \mathrm{L}$ of the sample extract was mixed with Follin-Ciocalteau reagent $(1.5 \mathrm{~mL})$ and allowed to stand at $22{ }^{\circ} \mathrm{C}$ for $5 \mathrm{~min}$ before adding $\mathrm{NaNO}_{3}$ solution $\left(1.5 \mathrm{~mL}, 60 \mathrm{~g} \mathrm{~L}^{-1}\right)$. After two hours at $22{ }^{\circ} \mathrm{C}$, absorbance was measured at $725 \mathrm{~nm}$. The results were expressed as $\mathrm{mg} \mathrm{g}^{-1}$ gallic acid $^{-1}$ equivalent (mg GAE $\mathrm{g}^{-1}$ dry sample). For total flavonoids determination, samples $(1 \mathrm{~mL})$ were mixed with $\mathrm{NaNO}_{3}(0.3 \mathrm{~mL})$ in a test tube covered with aluminium foil and left to stand for 5 min. Then $10 \% \mathrm{AlCl}_{3}(0.3 \mathrm{~mL})$ was added followed by addition of $1 \mathrm{M} \mathrm{NaOH}(2 \mathrm{~mL})$. The absorbance was measured at $510 \mathrm{~nm}$ using a spectrophotometer with rutin as a standard (results expressed as $\mathrm{mg} / \mathrm{g}$ rutin dry sample). For every ABA treatment, 40 plants were used as replicates.

\subsection{Determination of Soluble Sugar}

Soluble sugar was measured spectrophotometrically using the method described by Ibrahim et al. [63]. Samples $(0.5 \mathrm{~g})$ were placed in $15 \mathrm{~mL}$ conical tubes, and distilled water added to make up the volume to $10 \mathrm{~mL}$. The mixture was then vortexed and later incubated for $10 \mathrm{~min}$. Anthrone reagent was 
prepared by dissolving anthrone (Sigma Aldrich, St. Louis, MO, USA, $0.1 \mathrm{~g}$ ) in 95\% sulphuric acid (Fisher Scientific, Los Angeles, CA, USA $50 \mathrm{~mL}$ ). Sucrose was used as a standard stock solution to prepare a standard curve for the quantification of sucrose in the sample. The mixed sample of ground dry sample in distilled water was centrifuged at a speed of 3,400 rpm for $10 \mathrm{~min}$ and then filtered to get the supernatant. A sample $(4 \mathrm{~mL})$ of the supernatant was mixed with anthrone reagent $(8 \mathrm{~mL})$ and then placed in a water-bath set at $100{ }^{\circ} \mathrm{C}$ for 5 min before the sample was measured at an absorbance of $620 \mathrm{~nm}$ using a model UV160U spectrophotometer (Shimadzu Scientific, Kyoto, Japan). The total soluble sugar in the sample was expressed as $\mathrm{mg} / \mathrm{g}$ sucrose dry sample. About 40 plants were used as replicates for every ABA treatment.

\subsection{Superoxide Radical $\left(\mathrm{O}_{2}^{-}\right)$Assay}

The assay for $\mathrm{O}_{2}^{-}$was carried out using the method of Wang et al. [64]. The $\mathrm{O}_{2}$ was generated by xanthine/xanthine-oxidase systems. Nitrite formation from hydroxylammonium chloride was determined at $530 \mathrm{~nm}$ in the spectrophotometer. The reaction mixture contained $1.0 \mathrm{~mL}$ of $65 \mathrm{mM}$ Na-phosphate buffer ( $\mathrm{pH} 7.8$ ), $0.1 \mathrm{~mL}$ of $7.5 \mathrm{mM}$ xanthine, $0.1 \mathrm{~mL}$ of $10 \mathrm{mM}$ hydroxylammonium chloride, $0.1 \mathrm{~mL}$ of fruit extract, and $0.4 \mathrm{~mL}$ of double-distilled $\mathrm{H}_{2} \mathrm{O}$. The reaction was started by addition of $0.3 \mathrm{~mL}$ of xanthine oxidase (containing $60 \mu \mathrm{g}$ of protein). The total reaction volume was $2.0 \mathrm{~mL}$ and incubated at $25{ }^{\circ} \mathrm{C}$ for $20 \mathrm{~min}$. Then, $0.5 \mathrm{~mL}$ was removed from the above reaction mixture, $0.5 \mathrm{~mL}$ of $19 \mathrm{mM}$ sulfanilic acid and $0.5 \mathrm{~mL}$ of $1.0 \%$-naphthylamine were added, and the mixture was shaken for $5 \mathrm{~min}$. After standing at room temperature for $20 \mathrm{~min}$, the optical density of the mixture was determined at $530 \mathrm{~nm}$ against blanks that had been prepared similarly but without plant extract. The final results were expressed as percent inhibition of $\mathrm{O}_{2}$ production in the presence of plant extract. The scavenging capacity of $\alpha$-tocopherol at various concentrations ( 1 to $25 \mu \mathrm{g}$ ) on superoxide radical $\left(\mathrm{O}_{2}\right)$ was measured and used for determining the $\mathrm{O}_{2}$ scavenging capacity of the plant extract. The antioxidant capacity of plant extract against the $\mathrm{O}_{2}$ value was expressed as $\mu$ mol of $\alpha$-tocopherol equivalent per gram dry weight. In each 12 experimental units, 40 plants were used as replicates.

\section{5. $\mathrm{H}_{2} \mathrm{O}_{2}$ Assay}

The hydrogen peroxide measurement was based on the method described by Petterson et al. [65]. Three hundred milligrams of the youngest, fully expanded leaf was homogenized in a cold mortar with $5 \mathrm{~mL} 5 \%$ trichloroacetic acid (TCA) containing $0.1 \mathrm{~g}$ activated charcoal and $0.1 \%$ polyvinylpolypyrrolidone (PVPP). The homogenate was filtered and centrifuged at 18,000 g for $10 \mathrm{~min}$. The supernatant was filtered through a Millipore filter $(0.45 \mathrm{~mm})$ and used in the assay. A $200-\mathrm{mL}$ aliquot was brought to $2 \mathrm{~mL}$ with $100 \mathrm{mM}$ potassium phosphate buffer $(\mathrm{pH} \mathrm{8.4)}$ ) and $1 \mathrm{~mL}$ of a colorimetric reagent was added. This reagent was prepared daily by mixing $1: 1(\mathrm{v} / \mathrm{v}) 0.6$ potassium titanium oxalate and $0.6 \mathrm{mM} \mathrm{4-2}$ (2-pyridylazo) resorcinol (disodium salt). After incubating the sample solution at $60{ }^{\circ} \mathrm{C}$ for $45 \mathrm{~min}$, the absorbance was measured at $508 \mathrm{~nm}$. Blanks were made by replacing plant extract with 5\% TCA. The antioxidant capacity of plant extract against $\mathrm{H}_{2} \mathrm{O}_{2}$ was expressed as $\mu$ mole of ascorbate equivalent per gram dry weight. About 40 plants were used as replicates for every ABA treatment. 


\subsection{Oxygen Radical Absorbance Capacity (ORAC) Assay}

The plant extracts were incubated with fluorescein as a free radical probe and AAPH as a free radical generator [66]. The kinetics of fluorescein degradation was read on a Spectra XMS Gemini microplate reader (Molecular Devices, Sunnyvale, CA, USA). A sample of 6-hydroxy-2,5,7,8tetramethylchroman-2-carboxylic acid (Trolox) was used to generate a standard curve. The results of the antioxidant capacity of plant extracts were expressed as $\mu$ mol Trolox equivalent per gram of fresh sample $(\mu \mathrm{mol} \mathrm{TE} / \mathrm{g})$. For every ABA treatment, 40 plants were used as replicates.

\subsection{DPPH Assay}

The DPPH scavenging activities of freeze dried blueberries were measured using a standard method [53]. Twenty milligrams of DPPH was dissolved in $100 \mathrm{~mL}$ of methanol to make a DPPH stock solution. The DPPH working solutions were freshly prepared by mixing $3.5 \mathrm{~mL}$ DPPH stock solution and $6.5 \mathrm{~mL}$ methanol. The absorbance at $515 \mathrm{~nm}$ was measured on a Spectra max 190 microplate reader (Molecular Devices). The plant extracts $(50 \mu \mathrm{L})$ were added to $950 \mu \mathrm{DPPH}$ working solution and samples were kept at room temperature in the dark for $60 \mathrm{~min}$. Trolox solutions were added to DPPH working solutions as standards. The results of the DPPH scavenging activity were expressed as $\mu \mathrm{mol}$ Trolox equivalent per gram of fresh plant sample ( $\mu$ mol TE/g). In each 12 experimental units, 40 plants were used as replicates.

\subsection{Phenylalanine Ammonia-Lyase (PAL) Activity}

Phenylalanine-ammonia-lyase (PAL) activity was measured using the method described by Martinez and Lafuante [67]. The enzyme activity was determined by spectrophotometrically measuring the production of trans-cinnamic acid from L-phenylalanine. Enzyme extract $(10 \mu \mathrm{L})$ was incubated at $40{ }^{\circ} \mathrm{C}$ with $12.1 \mathrm{mM}$ L-phenylalanine $(90 \mu \mathrm{L}$, Sigma) that was prepared in $50 \mathrm{mM}$ Tris$\mathrm{HCl}$, ( $\mathrm{pH}$ 8.5). After 15 min of reaction, trans-cinnamic acid yield was estimated by measuring increase in the absorbance at $290 \mathrm{~nm}$. The standard curve was prepared by using a trans-cinnamic acid standard (Sigma) and the PAL activity was expressed as nM trans-cinnamic acid $\mu \mathrm{g}$ protein ${ }^{-1} \mathrm{~h}^{-1}$. In each 12 experimental units, 40 plants were used as replicates.

\subsection{Leaf Gas Exchange Measurement}

The measurements were obtained using a closed infra-red gas analyzer LICOR 6400 Portable Photosynthesis System (IRGA, Licor. Inc. Omaha, NE, USA). Prior to use, the instrument was warmed for $30 \mathrm{~min}$ and calibrated with the ZERO IRGA mode. Two steps are required in the calibration process: first, the initial zeroing process for the built-in flow meter; and second, zeroing process for the infra-red gas analyzer. The measurements used optimal conditions set at $400 \mu \mathrm{mol} \mathrm{mol}^{-1}$ $\mathrm{CO}_{2}, 30{ }^{\circ} \mathrm{C}$ cuvette temperature, $60 \%$ relative humidity with air flow rate set at $500 \mathrm{~cm}^{3} \mathrm{~min}^{-1}$, and modified cuvette condition of $800 \mu \mathrm{molm}^{-2} \mathrm{~s}^{-1}$ photosynthetically photon flux density (PPFD). The measurements of gas exchange were carried out between 09:00 to 11:00 a.m. using fully expanded young leaves numbered three and four from the plant apex to record net photosynthesis rate (A). The operation was automatic and the data were stored in the LI-6400 console and analyzed with the 
Photosyn Assistant software (Version 3, Lincoln Inc., Columbus, OH, USA). Several precautions were taken to avoid errors during measurements [68]. About 40 plants were used as replicates in each ABA treatment.

\subsection{Antioxidant Enzyme Activity}

\subsubsection{Preparation of Enzyme Extracts}

To determine the enzymatic activity of the antioxidant proteins, a crude enzyme extract was prepared by homogenizing $500 \mathrm{mg}$ of leaf tissue in extraction buffer containing $0.5 \%$ Triton X-100 and $1 \%$ polyvinylpyrrolidone in $100 \mathrm{mM}$ potassium phosphate buffer $(\mathrm{pH} 7.0)$ using a chilled mortar and pestle. The homogenate was centrifuged at $15,000 \mathrm{rpm}$ for $20 \mathrm{~min}$ at $4{ }^{\circ} \mathrm{C}$. The supernatant was used in the enzymatic assays described below. For every ABA treatment, 40 plants were used as replicates.

\subsubsection{Ascorbate Peroxidase (APX) Activity Assay}

Ascorbate peroxidase activity (APX, EC 1.11.1.11) was determined spectophotometrically by a decrease in the absorbance at $265 \mathrm{~nm}$ using the method of Nakano and Asada [41]. The reaction mixture contained $50 \mathrm{mM}$ potassium phosphate buffer $\mathrm{pH} 7.0,5 \mathrm{mM}$ ascorbate, $0.5 \mathrm{mM} \mathrm{H}_{2} \mathrm{O}_{2}$ and enzyme extract. For every ABA treatments, 40 plants was used as replicates

\subsubsection{Catalase (CAT) Activity Assay}

Catalase activity (CAT; EC 1.11.1.6) was determined by consumption of $\mathrm{H}_{2} \mathrm{O}_{2}$ using the method of Aebi [69]. The reaction mixture $(3 \mathrm{~mL})$ contained $50 \mathrm{mM}$ potassium phosphate buffer $\mathrm{pH} 7.0,15 \mathrm{mM}$ $\mathrm{H}_{2} \mathrm{O}_{2}$ and $50 \mu \mathrm{L}$ enzyme extract. The reaction was initiated by adding the $\mathrm{H}_{2} \mathrm{O}_{2}$. The consumption of $\mathrm{H}_{2} \mathrm{O}_{2}$ was monitored spectrophotometrically at $240 \mathrm{~nm}$ for $3 \mathrm{~min}$. Enzyme activity was expressed in $\mu \mathrm{M} \mathrm{H}_{2} \mathrm{O}_{2} \mathrm{~min}^{-1}$.

\subsubsection{Superoxide Dismutase (SOD) Activity Assay}

The activity of SOD (EC 1.15.1.1) was determined by measuring its ability to inhibit the photoreduction of nitro blue tetrazolium (NBT) according to the method of Giannopolitis and Ries [70]. The reaction solution $(3 \mathrm{~mL}$ ) contained $50 \mu \mathrm{mol}$ NBT, 1.3 riboflavin, $13 \mathrm{mmol}$ methionine, $75 \mathrm{nmol}$ EDTA, $50 \mathrm{mmol}$ phosphate buffer $(\mathrm{pH} 7.8)$ and $50 \mu \mathrm{L}$ enzyme extract. The reaction solution was irradiated under fluorescent light at $75 \mu \mathrm{mol} \mathrm{m} \mathrm{m}^{-1}$ for $15 \mathrm{~min}$. The absorbance at 560 was read against a blank (non-irradiated reaction solution). One unit of SOD activity was defined as the amount of enzyme that inhibited $50 \%$ of NBT photoreduction.

\subsection{LOX Inhibitory Assay}

Lipoxygenase (LOX) was assayed according to the method reported by $\mathrm{Wu}$ [71]. A mixture of a solution of sodium borate buffer $(1 \mathrm{~mL}, 0.1 \mathrm{M}, \mathrm{pH} 8.8)$ and soybean LOX $\left(10 \mu \mathrm{L}, 9000 \mathrm{U} \mathrm{mL}^{-1}\right)$ was incubated with the plant extract sample $(10 \mu \mathrm{L})$ in a $1 \mathrm{~mL}$ cuvette at room temperature for $5 \mathrm{~min}$. The 
reaction was initiated by the addition of linoleic acid substrate $(10 \mu \mathrm{L}, 10 \mathrm{mmol})$. The absorbance of the resulting mixture was measured at $234 \mathrm{~nm}$ over time at a rate of one measurement/min (6 readings). Inhibition of LOX was assessed using the following equation:

$\%$ Inhibition $=100 \times($ absorbance of the control - absorbance of the sample $) /($ absorbance of the control)

The effective concentration $\left(\mu \mathrm{g} \mathrm{mL}^{-1}\right)$ at which LOX activity is inhibited by $50 \%\left(\mathrm{IC}_{50}\right)$ was represented on a graph. Nordihydroguaiaretic acid (NDGA) was used as the positive standard. For every ABA treatment, 40 plants were used as replicates.

\subsection{Statistical Analysis}

Data were analyzed using the analysis of variance procedure in SAS version 17. Means separation was performed using Duncan multiple range test and the standard error of differences between means was calculated with the assumption that the data were normally distributed and equally replicated $[72,73]$.

\section{Conclusions}

In conclusion, this work reveals that the use of ABA can enhance the production of primary and secondary metabolites in O. stamineus. The study showed increased oxidative stress (APX, CAT, SOD) at high application rates of $\mathrm{ABA}$ and improved production of phytochemicals (total phenolics and flavonoids). This showed that application of foliar ABA can be useful tool to enhance secondary metabolites properties of this plant.

\section{Acknowledgements}

The authors are grateful to the Ministry of Higher Education Malaysia for financing this work under the Research University Grant Scheme No. 91007.

\section{Conflict of Interest}

The authors declare no conflict of interest.

\section{References}

1. Akuwoah, A.; Zhari, G.; Norhayati, I.; Sadikun, A. The effects of different extraction solvents of varying polarities on polyphenols of Orthosiphon stamineus and evaluation of the free radical-scavenging activity. Food Chem. 2005, 93, 311-317.

2. Akuwoah, A.; Zhari, G.; Norhayati, I.; Sadikun, A.; Khamsah, S.M. Sinensitin, eupatorin, 30-hydroxy-5,6,7, 40-tetramethoxyflavone and rosmarinic acid contents and antioxidative effect of Orthosiphon stamineus from Malaysia. Food Chem. 2004, 87, 559-566.

3. Sumaryono, W.; Proksch, P.; Wray, V.; Witte, L.; Hartmann, T. Qualitative and quantitative analysis of phenolic constituents from Orthosiphon aristatus. Planta Med. 1991, 57, 176-180. 
4. Tezuka, Y.; Stampoulis, P.; Banskota, A.; Awale, H.; Tran, H.; Saiki, K.Q. Constituents of the Vietnamese medicinal plant Orthosiphon stamineus. Chem. Pharma. Bull. 2000, 48, 1711-1719.

5. Mamoudou, H.D. Endogenous phenolics and starch modifying enzymes as determinats of sorghum for food use in Burkina Faso. Ph.D. Thesis, Wageningen University, The Netherlands, 2005.

6. Djousse, L.; Arnett, D.K.; Coon, H.; Province, M.A.; Moore, L.L.; Ellison, R.C. Fruit and vegetable consumption and LDL cholesterol: The National Heart, Lung, and Blood Institute Family Heart Study. Am. J. Clinical Nut. 2004, 79, 213-217.

7. Ector, B.J.; Magee, J.B.; Hegwood, C.B.; Coign, M.J. Resveratrol concentration in muscadine berries, juice, pomace, purees, seeds, and wines. Am. J. Enol. Vitic. 1996, 47, 57-62.

8. Treutter, D. Managing phenol contents in crop plants by phytochemical farming and breedingvisions and constraints. Int. J. Mol. Sci. 2010, 11, 807-857.

9. Cantín, C.M.; Fidelibus, M.W.; Crisosto, C.H. Application of abscisic acid (ABA) at veraison advanced red colour development and maintained postharvest quality of 'Crimson Seedless' grapes. Postharvest Biol. Tech. 2007, 46, 237-241.

10. Jiang, M.; Zhang, J. Effect of Abscisic acid on active oxygen species, antioxidative defence system, and oxidative damage in leaves of maize seedlings. Plant Cell Physiol. 2001, 42, 1265-1273.

11. Cuello, J.; Quiles, M.J.; Rosauro, J.; Sabate, B. Effects of growth regulators and light on chloroplasts NAD $(\mathrm{P}) \mathrm{H}$ dehydrogenase activities of senescent barley leaves. Plant Growth Regul. 1995, 17, 225-232.

12. Li, Z.; Zhao, X.; Sandhu, A.K.; Gu, L. Effects of exogenous abscisic acid on yield, antioxidant capacities, and phytochemical contents of greenhouse grown lettuces. J. Agric. Food Chem. 2010, $58,6503-6509$.

13. Sandhu, A.K.; Gray, D.J.; Lu, J.; Gu, L. Effects of exogenous abscisic acid on antioxidant capacities, anthocyanins, and flavonol contents of muscadine grape (Vitis rotundifolia) skins. Food Chem. 2010, 126, 982-988.

14. Pei, Z.M.; Murata, N.; Benning, G.; Thomine, S.; Klusener, B.; Allen, G.J.; Grill, E.; Schroeder, J.I. Calcium channels activated by hydrogen peroxide mediate abscisic acid signaling in guard cells. Nature 2000, 406, 731-734.

15. Lin, C.C.; Kao, C.H. Abscisic acid induced changes in cell wall peroxidase activity and hydrogen peroxide level in roots of rice seedlings. Plant Sci. 2001, 160, 323-329.

16. Lu, S.; Su, W.; Li, H.; Guo, Z. Abscisic acid improves drought tolerance of triploid bermuda grass and involves $\mathrm{H}_{2} \mathrm{O}_{2}$ and $\mathrm{NO}$ induced antioxidant enzyme activities. Plant Physiol. Biochem. 2009, 47,132-138.

17. Bueno, P.; Piqueras, A.; Kurepa, J.; Savoure, A.; Verbruggen, N.; Van Montagu, M.; Inze, D. Expression of antioxidant enzymes in response to abscisic and high osmoticum in tobacco BYcell cultures. Plant Sci. 1998, 138, 27-34.

18. Hung, K.T.; Kao, C.H. Hydrogen peroxide is necessary for abscisic acid-induced senescence of rice leaves. J. Plant Physiol. 2004, 161, 1347-1357.

19. Jannat, R.; Uraji, M.; Morofuji, M.; Islam, M.M.; Bloom, R.E.; Nakmura, Y.; McClung, C.R.; Schroeder, J.I.; Mori, I.C.; Murata, Y. Roles of intracellular hydrogen peroxide accumulation in abscisic acid signaling in Arabidopsis guard cells. J. Plant Physiol. 2011, 14, 112-123. 
20. Quan, L.J.; Zhang, B.; Shi, W.W.; Li, H.Y. Hydrogen peroxide in plants: A versatile molecule of the reactive oxygen species network. J. Integr. Plant Biol. 2008, 50, 2-18.

21. Tsai, Y.C.; Kao, C.H. The involvement of hydrogen peroxide in abscisic acid-induced activities of ascorbate peroxidase and glutathione reductase in rice roots. Plant Growth Regul. 2004, 43, $207-212$.

22. Hu, X.; Zhang, A.; Zheng, J.; Jiang, M. Abscisic acid is a key inducer of hydrogen peroxide production in leaves of maize plants exposed to water stress. Plant Cell Physiol. 2006, 47, 1484-1495.

23. Cakmak, I.; Marschner, H. Magnesium deficiency and high light intensity enhance activities of superoxide dismutase, ascorbate peroxidase, and glutathione reductase in bean leaves. Plant Physiol. 1992, 98, 1222-1227.

24. Kataoka, L.; Sugiura, A.; Utsunomiya, N.; Tomana, T. Effects of abscisic acid and defoliation on anthocyanin accumulation in kyoto grapes (Vitis vinefera $\mathrm{x}$ lab ruscana BAILEY). Vitis 2011, 21, 325-332.

25. Wang, J.; Chen, J.; Pan, K. Effects of exogenous abscisic acid on the level of antioxidants in Atractylodes macrocephala Koids under lead stress. Env. Sci. Poll. Res. 1999, 12, 112-119.

26. Shui, Y.C.; Feng, X.; Yan, W. Advances in the study of flavonoids in Gingko bilobaleaves. J. Med. Plant Res. 2009, 3, 1248-1252.

27. Guo, R.; Yuan, G.; Wang, Q. Effect of sucrose and mannitol on the accumulation of health-promoting compounds and the activity of metabolic enzymes in broccoli sprouts. Sci. Hortic. 2011, 128, 159-165.

28. Bryant, J.P.; Chapin, F.S.; Klein, D.R. Carbon nutrient balance ofboreal plants in relation to vertebrate herbivory. Oikos 1983, 40, 357-368.

29. Herms, D.A.; Matson, W.J. The dilemma of plants: To grow or defend. Quar. Rev. Biol. 1992, 67, 283-335.

30. Panuelas, J.; Estiarte, M. Can elevated $\mathrm{CO}_{2}$ affect secondary metabolism and ecosystem function? Trends Ecol. Evol. 1998, 13, 20-24.

31. Yang, D.; Sheng, D.; Duan, Q.; Liang, X.; Liang, Z.; Liu, Y. PEG and ABA trigger the burst of reactive oxygen species to increase Tanshinone production in Salvia miltiorrhiza Hairy roots. J. Plant Growth Regul. 2012, 31, 579-587.

32. Ding, W.; Song, L.; Wang, X.; Bi, Y. Effects of abscisic acid on heat stress tolerance in the calli from the two ecotypes of Phragmites communis. Biol. Plant 2010, 54, 607-613.

33. Mansouri, H.; Asrar, Z.; Szopa, J. Effects of ABA on primary terpenoids and tetrahydrocannabitol in Cannabis sativa L. at flowering stage. Plant Growth Regul. 2009, 58, 269-277.

34. Jaafar, H.Z.E. Impact of Environmental Stress on Reproductive Development in Sweet pepper (Capsicum anuum). PhD Thesis, University of Nottingham, Nottingham, UK, 1995.

35. Travaglia, C.; Balboa, G.; Esposito, G.; Reinoso, H. ABA action on the production and redistribution of filed grown maize carbohydrates in semiarid regions. Plant Growth Regul. 2012, $67,27-34$.

36. Wang, S.; Hu, L.; Sun, J.; Sui, X.; Wei, Y.; Zhang, Z. Effects of exogenous abscisic acid on leaf carbohydrate metabolism during cucumber seedling dehyration. Plant Growth Regul. 2012, 66, 87-93. 
37. Szabó, B.; Lakatos, Á.; Koszegi, T.; Botz, L. Investigation of abiogenic stress-induced alterations in the level of secondary metabolites in poppy plants (Papaver somniferum L.). Acta Biol. Hung. 2008, 59, 425-438.

38. Ibrahim, M.H.; Jaafar, H.Z.E. The influence of carbohydrate, protein and phenylanine ammonia lyase on up-regulation of production of secondary metabolites (total phenolics and flavonoid) in Labisia pumila (Blume) Fern-Vill (Kacip Fatimah) under high $\mathrm{CO}_{2}$ and different nitrogen levels. Molecules 2011, 16, 4172-4190.

39. Jones, C.G.; Hartley, S.E. A protein competition model of phenolic allocation. Oikos 1999, 86, $27-44$.

40. Fatima, Z.; Bano, A. The effects of plant growth regulators and temperate shock on IAA-oxidase activity of roots and endogenous ABA level of leaves. Pak. J. Biol. 1999, 2, 1601-1603.

41. Nakano, Y.; Asada, K. Hydrogen peroxide is scavenged by ascorbate-specific peroxidase in spinach chloroplast. Plant Cell Physiol. 1981, 22, 867-880.

42. Guan, L.M.; Zhao, J.; Scandalice, J.G. Cis-element and trans-factors that regulate expression of the maize Cat 1 antioxidant gene in response to ABA and osmotic stress: $\mathrm{H}_{2} \mathrm{O}_{2}$ is likely intermediary signaling molecule for the response. Plant J. 2000, 22, 87-95.

43. Saleh, A.A.H. Amelioration of chilling injuries in mung bean (Vigna radiata L) seedlings by paclobutrazol, abscisic acid and hydrogen peroxide. Am. J. Plant Physiol. 2007, 2, 318-332.

44. $\mathrm{Hu}, \mathrm{X}$; Jiang, M.; Zhang, A.; Lu, J. Abscisic acid induced apoplastic $\mathrm{H}_{2} \mathrm{O}_{2}$ accumulation up-regulates the activities of chloroplastic and cytosolic antioxidant enzymes in maize leaves. Planta 2005, 223, 57-68.

45. Cui, B.; Liang, Z.; Liu, Y.; Liu, F.; Zhu, J. Effects of ABA and its biosynthetic inhibitor fluridone on accumulation of phenolic acids and activity of PAL and TAT in hairy root of Salvia miltiorrhiza. Zhongguo Zhongyao Zazhi 2012, 37, 754-759.

46. Duan, Y.Y.; Yue, X.; Chen, G.L. Effect of abscisic acid on wound healing and antioxidant enzyme activities of Cynomorium songaricum stem. Plant Physiol. J. 2012, 48, 298-302.

47. Pociecha, E.; Płazek, A.; Janowiak, F.; Zwierzykowski, Z. ABA level, proline and phenolic concentration, and PAL activity induced during cold acclimation in androgenic Festulolium forms with contrasting resistance to frost and pink snow mould (Microdochium nivale) Physiol. Mol. Plant Pathol. 2009, 76, 126-132.

48. Huang, D.; Ou, B.; Prior, R.L. The chemistry behind antioxidant capacity assays. J. Agric. Food Chem. 2006, 53, 1841-1856.

49. Kalt, W.; Ryan, D.A.; Duy, J.; Prior, R.L.; Ehlenfeldt, M.K.; Vander, K.S.P. Inter-specific variation in anthocyanin, phenolics and antioxidant capacity among genotypes o high bush and lowbush blueberries (Vaccinium section Cyanococcus spp). J. Agri. Food Chem. 2001, 49, 4761-4767.

50. Mahmoodzadeh, H.; Esparham, E. Changes in hydrogen peroxide content and antioxidant enzymes in Abscisic acid induced antioxidant defence in leaves of bean seedlings. Int. J. Bot. 2011, 7, 195-199.

51. Percival, D.M.; Joanna, L. Use of plant growth regulators to increase polyphenolic compounds in the wild blueberry. Agric. Inst. Can. 2007, 87, 333-336. 
52. Prior, R.L.; Hoang, H.; Gu, L.; Wu, X.; Bacchiocca, M.; Howard, L. Assays for hydrophylic and lipophilic antioxidant capacity (ORAC) of plasma and other biological and food samples. J. Agric. Food Chem. 2003, 51, 3273-3279.

53. Chaitanya, K.; Sundar, D.; Masilamani, S.; Ramachandra, R.A. Variation in heat stress induced antioxidant enzyme activities among three mulberry cultivars. Plant Growth Regul. 2002, 36, $175-180$.

54. Cakmak, I.; Horst, W.J. Effects of aluminium and lipid peroxidation, superoxide dismutase, catalase and peroxidase activities in root tips of soybean (Glycine max). Physiol. Plant 1991, 83, 463-468.

55. Khorsidi, M.; Nijavan, A.M. The effects of abscisic acid and $\mathrm{CaCl}_{2}$ on the activities of antioxidant enzymes under cold stress in maize seedlings in the dark. Pak. J. Biol. Sci. 2006, 9, 54-59.

56. Bowler, C.; Montagu, M.V.; Inze, D. Superoxide dismutase and stress tolerance. Ann. Rev. Plant Physiol. Mol. Bio. 1992, 43, 83-116.

57. Moreno, J.J. New aspects of the role of hydroxyeicosatetraenoic acids in cell growth and cancer development. Biochem. Pharmacol. 2009, 77, 1-10.

58. Dobrian, A.D.; Lieb, D.C.; Cole, B.K.; Taylor-Fishwick, D.A.; Chakrabarti, S.K.; Nadler, J.L. Functional and pathological roles of the 12- and 15-lipoxygenases. Prog. Lipid. Res. 2011, 50, $115-131$.

59. Kumaraswamy, M.V.; Satish, S. Antioxidant and anti-lipoxygenase activity of Thespesia lampas Dalz and Gibs. Advan. Biol. Res. 2008, 2, 56-59.

60. Woese, K.; Lange, D.; Boess, C; Bögl, K.W. A comparison of organically and conventionally grown foods-Results of a review of the relevant literature. J. Sci. Food Agric. 1997, 74, 281-293.

61. Buran, T.J.; Sandhu, A.K.; Azeredo, A.M.; Bent, A.H.; Wiliamson, J.G.; Gu, L. Effect of exogenous abscisic acid on fruit quality, antioxidant capacities and phytochemical contents of southern high bush blueberries. Food Chem. 2012, 132, 1375-1381.

62. Ibrahim, M.H.; Jaafar, H.Z.E. Primary, secondary metabolites, $\mathrm{H}_{2} \mathrm{O}_{2}$, Malondialdehyde and photosynthetic responses of Orthosiphon stimaneus Benth. to different irradiance levels. Molecules 2012, 17, 1159-1176.

63. Ibrahim, M.H.; Jaafar, H.Z.E. Impact of elevated carbon dioxide on primary, secondary metabolites and antioxidant responses of Eleais guineensis Jacq. (Oil Palm) seedlings. Molecules 2012, 17, 5195-5211.

64. Wang, Y.S.H.; Bunce, A.J.; Maas, L.J. Elevated carbon dioxide increases contents of antioxidant compounds in field-grown strawberries. J. Agric. Food Chem. 2003, 51, 4315-4320.

65. Patterson, B.D.; MacRae, E.A.; Ferguson, I.B. Estimation of hydrogen peroxide in plant extracts using titanium (IV). Anal. Biochem. 1984, 139, 487-492.

66. Brands, W.W.; Cuvelier, M.E.; Berset, C. Use of free radical method to evaluate antioxidant activity. Food Sci. Tech. 1995, 28, 25-80.

67. Martínez-Téllez, M.A.; Lafuénte, M.T. Effects of high temperature conditioning on ethylene, phenylalanine ammonia lyase, peroxidase and polyphenol oxidase in flavedo of chilled "Fortune" mandarin fruit. J. Plant Physiol. 1997, 150, 674-678. 
68. Ibrahim, M.H.; Jaafar, H.Z.E. Photosynthetic capacity, photochemical efficiency and chlorophyll content of three varieties of Labisia pumila benth. exposed to open field and greenhouse growing conditions. Acta Physiol. Plant. 2011, 33, 2179-2185.

69. Aebi, H. Catalase. Methods of Enzymatic Analysis, 3rd ed.; Bergmeyer, H., Verlag, C., Weinheim, A., Eds.; Scientific Pulication, VA, USA, 1983.

70. Giannopolitis, C.N.; Ries, S.K. Superoxide dismutase: Occurance in higher plants. Plant Physiol. 1977, 59, 309-314.

71. Wu, H. Affecting the activity of soybean lipoxygenase-1. J. Mol. Graph. 1996, 14, 331-337.

72. Ibrahim, M.H.; Jaafar, H.Z.E. Reduced Photoinhibition under Low irradiance enhanced Kacip Fatimah (Labisia pumila Benth) secondary metabolites, Phenyl Alanine Lyase and antioxidant activity. Int. J. Mol. Sci. 2012, 13, 5290-5306.

73. Ibrahim, M.H.; Jaafar, H.Z.E.; Rahmat, A.; Rahman, Z.A. Involvement of nitrogen on flavonoids, glutathione, anthocyanin, ascorbic acid and antioxidant activities of Malaysian medicinal plant Labisia pumila Blume (Kacip Fatimah). Int. J. Mol. Sci. 2012, 13, 393-408.

Sample Availability: Not available.

(C) 2013 by the authors; licensee MDPI, Basel, Switzerland. This article is an open access article distributed under the terms and conditions of the Creative Commons Attribution license (http://creativecommons.org/licenses/by/3.0/) 